\title{
血液濃縮製剤治療中の血友病患者 における細胞性免疫機能に関する検討
}

\begin{tabular}{|c|c|c|c|c|}
\hline 安部 & 英* & 風間 & 睦美* & 木下 \\
\hline 田 & 重三* & 川杉 & 和夫* & 吉村 \\
\hline 地 & 研吾* & 柳 & 富子* & 斎藤 \\
\hline
\end{tabular}

Studies on cellular immune functions of hemophiliacs under treatment with concentrate of antihemophilic factor

Takeshi ABE*, Mutsuyoshi KAZAMA*, Tadatoshi KINOSHITA*, Juzo MATSUDA*, Kazuo KAWASUGI*, Yūichi YOSHIMURA*, Kengo GOHCHI*, Tomiko RYU* and Noriko SAITOH*

There have been reported many cases of acquired immune deficiency syndrome (AIDS) among the groups of homosexuals, drug addicts, Haitian immigrants, prisoners and hemophiliacs under treatment with concentrate of antihemophilic factors in the United States and many European countries, but no case of definite AIDS has been reported in Japan so far yet.

Authors have observed two possible cases of AIDS in hemophiliacs, one of whom had high fever, generalized lymphadenopathy and splenomegaly, and died of sepsis with Campylobacter jejunii. The other surviving one was revealed abnormality of $\mathrm{T}$ cell subsets of peripheral lymphocytes. These observations prompted us to investigate the cellular immunity of hemophiliacs to find whether any case of apparent or latent AIDS was included in them.

Twenty one hemophiliacs (17 cases of hemophilia A and 4 cases of hemophilia B) were investigated their cullular immune functions of peripheral lymphocytes to prove that responsiveness of lymphocytes to mitogens (PHA and PWM) was

* 帝京大学医学部第一内科 [干173 東京都板橋区加賀 2-11-1], The First Department of Medicine, Teikyo University Sclool of Medicine, Tokyo, Japan. 
impaired at various degrees, and the number of $\mathrm{T}_{4}$ (helper/inducer) and $\mathrm{T}_{8}$ (suppressor/cytotoxic) positive lymphocytes was decreased moderately or markedly, giving significant depression of $T_{4} / T_{8}$ ratio in all cases of hemopilia $A$ and 3 in 4 cases of hemophilia B. These data showed good concordance with the decrease of natural killer (NK) activity and $\mathrm{T}$ cell colony forming activity.

\section{はじめに}

最近各方面で注目されてきた，いわゆる後天 性免疫不全症候群 (acquired immune deficiency syndrome : AIDS) の臨床症状および検査所見 のらち, 米国連邦疾病予防 センター (Center of Disease Control : CDC) が重要なものとして 挙げているものの 1 つに細胞性免疫, ことに 細胞免疫機能の低下とそれに繫る日和見感染症 扣よびカリ二肺囊虫肺炎 (Pneumocystis carinii peumonia：PCP) がある.したがって本症候群 の診断にはリンパ球の生態,なかでも細胞性免 疫機能の不全所見が重要な条件とされてい $る^{1-7)}$.

しかしてこれ迄に発表された AIDS 患者のな かにここような病態にある対象から採った血 液を原料として作った血液製剤を治療のために 輸注された血友病患者からの発症が報告されて いて ${ }^{8 \sim 12)}$ ，血液製剤による補充療法が唯一の合 理的療法である血友病患者にとり，この AIDS の診断と対策は極めて深刻な意義を持つことと なった。

著者らは最近 AIDS に似た臨床症状を示した 2 例の血友病患者を経験し，報告したが ${ }^{13)}$ ，そ のほかにすでに長く，また多量にこのような血 液製剤の輸注を繰返し，現在正常な日常生活を 送っている血友病患者について，リンパ球を中 心とした細胞性免疫機能，すなわちリンパ球の 減少, phytohemagglutinin (PHA), あるいは pokeweed mitogen (PWM) 等に対するリン 八球の芽球化反応の低下, monoclonal 抗体に よる T cell subsets の分類変化, natural killer (NK) 細胞の減少などについて検討したので報 告する.

\section{I. 対象ならびに方法}

\section{1. 対 象}

検索の対象は，帝京大学第一内科外来に定期 的診察, あるいは出血時の補充療法のために通 院中の血友病患者の一部 21 例(血友病A 17 例, 血友病 B 4 例）である.な抽,このうち 1 例は 臨床所見から一応 AIDS の疑いがあるものと診 断された血友病 B 患者である（症例 18）.

被検患者の年齢は 12 歳から 56 歳に分布し, 凝固因子欠乏の程度は軽症から重症まで多様 で，本研究実施時までに打ける第壮因子，また は第IX因子濃縮製剤の補充量, 補充頻度もまた 千差万別であった.

免疫学的検查を行う 1 週間前より, リンパ球 機能に影響を括よぼす薬剤を服用していないこ とを確認し，また本研究の主旨を充分説明した らえで, 患者より採血し以下の実験に供した.

\section{2. 検査方法}

a .リンパ球幼若化反応

患者より採取したへパリン処理血をリン酸緩 衝液 (PBS) にて $2 \sim 3$ 倍に希勫したのち, Ficoll-Hypaque 液に重層し，1,900 rpm 20 分 間遠沈して境界に得られるリンパ球層をさらに PBS で 2 回遠沈洗浄し，これを $5 \times 10^{5} / \mathrm{m} l$ に なるよう $5 \%$ fetal calf serum（仔牛血清）加 RPMI-1640 (日水製薬) 培養液に浮遊した.

これの $200 \mu l$ を,最適,最高ならぴに最小の リンパ球幼若化を惹起するように調整した 3 濃 度の phytohemagglutinin (HPA)抌よぴ pokeweed mitogen (PWM) とともに，マイクロプ レート（住友ベークライト）に播種し， PHA 添加群は 72 時間, $\mathrm{PWM}$ 添加群は 96 時間 $\mathrm{CO}_{2}$ 培養器中で培養した，収穫 4 時間前に ${ }^{3} \mathrm{H}$-thy- 
midine $(5 \mu \mathrm{Ci})$ でパルスし,グラスフィルター 上に培養細胞を採取し, 液体シンチレーション カウンターで計測して，その幼若化率を stimulation index (SI) で表現した（正常 SI は PHA $130 \pm 20$, PWM $110 \pm 15$ ).

b. T cell colony 形成試験

$\mathrm{T}$ cell コロニー形成試験は, 仁保 ${ }^{14)} ら の$ 方法 を一部改変して実施した。

すなわち，リンパ球幼若化反応の項で述べた と同様の方法で患者リンパ球を分離したのち, これを MEM 培養液 (日水製薬) に $1 \times 10^{6}$ / $\mathrm{m} l$ になるよう浮遊させた. この浮遊液 $0.1 \mathrm{~m} l$ を, 沸騰蒸留中で溶解し， 2 倍濃縮 MEM 培養 液で調整した $2.2 \%$ メチルセルロース（Dow chemical) $0.4 \mathrm{ml}, 10 \%$ 仔牛血清加 1 倍 $\mathrm{MEM}$ 培養液 $0.4 \mathrm{~m} l$ 抢よび PHA $0.1 \mathrm{~m} l \quad(100 \mu \mathrm{g})$ とマイクロペトリディッシュ $(35 \times 10 \mathrm{~mm}, \mathrm{Fal}-$ con）中に植光込んだのち， $37^{\circ} \mathrm{C}, 5 \% \mathrm{CO}_{2}$ 存 在下で $4 \sim 5$ 日間培養した. その後, 光学顕微 鏡下で観察し, 50 個以上の細胞で形成されてい る細胞集団を 1 つのコロニーと判定して, ディ ッシュ中の全視野のコロニー数を数え, その值 を $\mathrm{T}$ cell コロニー形成能とした。な拈, 本試 験は duplicate で行なった.（正常值はコロニー 形成 100 個以上/ディッシュ)

c. T cell サブセットの解析

T cell サブセットの分類は, リンパ球蛍光自 動分析器（スペクトラムIII, Ortho 社）を使用 して実施した.

患者より採血したヘパリン処理血 $100 \mu l$ を PBS で 2 倍に希釈したのち，添付説明書の指 定通り，PBS で希䣋した T cell サブセットに 対する各種蛍光標識モノクローナル抗体 (OKT 3,4 特よび 8 , Ortho 社) $10 \mu l$ と混和し, $4^{\circ} \mathrm{C}$ にて 30 分間反応させた. その後リンパ球浮遊液 に添付の溶血試薬 $2 \mathrm{ml}$ を加光, 上く転倒混和 して 10 分間放置したのち遠疒し，上清を除去後 リンパ球沈査を $1 \mathrm{~m} l$ のPBS に再浮遊してス ペクトラムIIIを用いリンパ球サブセットを分析 した. (正常值 $\mathrm{T} 4 / \mathrm{T} 8$ 比 1.2 以上)

d. Natural killer (NK) 活性の測定

先に述べた Ficoll-Hypaque 比重遠沈法によ り，患者リンパ球を分離し， $10 \%$ 仔牛血清加
RPMI-1640 培養液にて， $5 \times 10^{6} / \mathrm{m} l$ に調製し effector cell とした.

また target cell は, 継代培養した K-562 細 胞を ${ }^{51} \mathrm{Cr} て ゙ ~ 37^{\circ} \mathrm{C} 1$ 時間ラベルし, 遠沈洗浄し たのち，上記培養液にて $1 \times 10^{5} / \mathrm{m} l$ に調製し 作製した。なお，特記した場合以外は effector および target cell 作製中の全ての操作を $4^{\circ} \mathrm{C}$ にて実施した.

この effector cell $(100 \mu l)$ と target cell $(100 \mu l)$ とをその比が 50：1 になるように V 底プレート (Falcon) に注入し, $37^{\circ} \mathrm{C} 4$ 時間 $\mathrm{CO}_{2}$ の存在下で反応させて遠沈したのち, 上清 を採取して，「カウンターで計測した。この值 (cpm) を自然解離 (SP) [target cell $(100 \mu l)$ と培養液 $(100 \mu l)$ とを反応させたコントロー ルの示す值]和よび最大解離 cpm(Max) [target cell $(100 \mu l)$ に $1 \mathrm{~N} \mathrm{HCl}(100 \mu l)$ を加 えた群の上清值】とから, 次式により検体の NK cell 活性 (\%) を求めた.

$$
\mathrm{NK} \text { cell活性 }(\%)=\frac{\text { 検体の } \mathrm{cpm}-\mathrm{SPcpm}}{\mathrm{Max} \mathrm{cpm}-\mathrm{SPcpm}} \times 100
$$

（正常値下限 $30 \%$ ）

\section{II. 結 果}

\section{1. リンパ球幼若化反応}

表 1 にまとめて示したごとく，リンパ球幼若 化反応を実施できた血友病 $\mathrm{A}$ 患者 6 例中 2 例 （症例 2,7）で, PHA のいずれの濃度に対して も反応性が著明に低下していた。

また，PWM に対する反応は 6 例全例で軽度 ないし高度の反応性低下を示した。な敃, PHA および PWM いずれに対しても幼若化反応が 著明に低下を示した症例は 2 例（症例 2,7）で あった。

血友病 B（症例 18～21）に扣いては，1 例に のみ本反応を実施できたが（症例 20）, PHA， PWM いずれの mitogen に対しても，その反 応は著明に低下していた。

\section{NK cell 活性}

NK cell 活性は，正常下限を $30 \%$ とした場 合, 血友病 A 18 症例中 7 例に，また血友病 B 4 症例中 1 例に低下をみた。 このらち, 臨床的 に AIDS と思われる症例 18 の NK cell 活性 
Blood \& Vessel 1983

Table 1 Lymphocyte-subset analysis and functional assays in hemophiliacs (No. 1 17, hemophilia A, $8 \sim 21$, hemophilia B)

\begin{tabular}{|c|c|c|c|c|c|c|c|c|c|c|c|c|c|c|}
\hline \multirow{3}{*}{ Case } & \multirow{3}{*}{$\begin{array}{l}\text { WBC } \\
(/ \mu \ell)\end{array}$} & \multirow{3}{*}{$\begin{array}{c}\text { Lymphocyte } \\
\text { Count } \\
(\%)\end{array}$} & \multicolumn{6}{|c|}{ Mitogen Stimulation Index (S.I.) of Lymphocytes } & \multirow{3}{*}{$\begin{array}{l}\text { T cell colony } \\
\text { formation } \\
\qquad(/ \mu \ell)\end{array}$} & \multicolumn{4}{|c|}{$T$ Cell Subsets (\%) } & \multirow{3}{*}{$\begin{array}{c}\text { NK cell } \\
\text { activity } \\
(\%)\end{array}$} \\
\hline & & & \multicolumn{3}{|c|}{ PHA } & \multicolumn{3}{|c|}{ PWM } & & \multirow{2}{*}{ ОКТ 3} & \multirow{2}{*}{ OKT 4} & \multirow{2}{*}{ OKT 8} & \multirow{2}{*}{$\begin{array}{c}\text { OKT 4/OKT } 8 \\
\text { Ratio }\end{array}$} & \\
\hline & & & $0.5 \mu \mathrm{g}$ & $10 \mu \mathrm{g}$ & $50 \mu \mathrm{g}$ & $0.5 \mu \mathrm{g}$ & $10 \mu \mathrm{g}$ & $25 \mu \mathrm{g}$ & & & & & & \\
\hline 1.E.M. & 7000 & 56 & & & & & & & & 66 & 13 & 49 & 0.2 & 29.1 \\
\hline 2.K.K. & 6500 & 46 & 1.0 & 21.4 & 46.0 & 1.6 & 2.2 & 3 & 4 & 64 & 22 & 38 & 0.5 & 35.7 \\
\hline 3. K.H. & 6700 & 56 & 11.5 & 241.4 & 150.8 & 90.8 & 63.1 & 44.5 & 56 & 56 & 14 & 38 & 0.4 & \\
\hline 4.H.H. & 5200 & 45 & 1.86 & 151.4 & 114.5 & 1.8 & 52.7 & 51.0 & 74 & 54 & 22 & 30 & 0.7 & \\
\hline 5.Y.H. & 4900 & 32 & 3.1 & 190.0 & 176.0 & 8.7 & 36.5 & 26.0 & 64 & 75 & 25 & 51 & 0.4 & 17.2 \\
\hline 6.M.O. & 2800 & 22 & 8.1 & 217.0 & 116.0 & 6.9 & 11.4 & 11.2 & 5 & 20 & 8 & 10 & 0.8 & 68.8 \\
\hline 7. K.0. & 5900 & 42 & 0.7 & 2.6 & 6.9 & 7.4 & 10.1 & 6.5 & 32 & 69 & 25 & 48 & 0.5 & 18.2 \\
\hline 8.S.M. & 8800 & 44 & & & & & & & 2 & 58 & 31 & 28 & 1.1 & 65.8 \\
\hline 9.T.T. & 5100 & 59 & & & & & & & 1 & 70 & 34 & 32 & 1.06 & 58.4 \\
\hline 10.K.G. & 7500 & 37 & & & & & & & 0 & 69 & 40 & 34 & 1.1 & 63.9 \\
\hline 11. H.K. & & & & & & & & & & 60.1 & 35.8 & 28.8 & 1.2 & 64.4 \\
\hline 12. M.K. & 4700 & 39 & & & & & & & & 70 & 31 & 39 & 0.7 & 62.7 \\
\hline 13. N.A. & & & & & & & & & & 76 & 29 & 46 & 0.6 & 51.3 \\
\hline 14. K.G. & 5900 & 52 & & & & & & & & 71 & 31 & 38 & 0.8 & 39.9 \\
\hline 15. Y.T. & 5900 & 25 & & & & & & & & 76 & 30 & 44 & 0.6 & 27.4 \\
\hline 16.Y.H. & 4200 & 44 & & & & & & & 195 & 47 & 15 & 24 & 0.6 & 20.5 \\
\hline 17. T.M. & 7000 & 30 & & & & & & & & 80 & 19 & 58 & 0.3 & 22.9 \\
\hline 18. H.M. & 5700 & 17 & & & & & & & 10 & 62 & 36 & 38 & 0.9 & 1.8 \\
\hline 19. M.I. & 7900 & 26 & & & & & & & 1 & 70 & 29 & 41 & 0.7 & 30.4 \\
\hline 20. H.K. & 4800 & 29 & & 1.8 & 1.1 & & 1.3 & 2.1 & 128 & 74 & 30 & 48 & 0.6 & 59.2 \\
\hline 21.K.S. & & & & & & & & & & 67 & 38 & 24 & 1.5 & 37.0 \\
\hline
\end{tabular}

は $1.8 \%$ と著明に低下していた.

\section{3. $\mathbf{T}$ cell colony 形成能}

$\mathrm{T}$ cell colony 形成試験を実施できたのは, 血友病 A 10 例抒よび血友病 B 3 例であるが, 血友病 $\mathrm{A} て ゙ \mathrm{~T}$ cell colony 形成能の著明な低下 (colony 数 10 個以下) を示したのは 5 例，中 等度以下（50 個以下） 1 例, 軽度低下（100 個 以下） 3 例であり，わずか 1 例（症例 17）の及 がほぼ正常な T cell colony 形成能を示した.

一方， 3 例の血友病 B のらち 2 例が著明な形 成能低下を示したが，他の 1 例はほぼ正常であ った。

\section{T cell subsets 解析}

OKT 3 抗体により同定されるリンパ球を T cell とみなした場合，絶対数の低下 $(1,000 / \mu l$ 以下）を示した血友病 $\mathrm{A}$ 症例は, 17 例中 1 例の みであった。

OKT 4 抗体と反応するリンパ球については,
17 例の血友病 $\mathrm{A}$ 症例中 4 例が著明な低下 $(20 \%$ 以下)，6例が軽〜中等度低下（30\% 以下）を 示し, 全体の $60 \%$ 近くが OKT 4 反応性リン パ球 (helper/inducer) 数の減少を示した.な 和以上の OKT 4 反応性リンパ球数の減少は相 対的のみならず，沉ど全ての症例で絶対数 の減少もみられた。

これに対し, 血友病 B 4 例中 1 例が著明な, また 2 例が軽〜中等度の減少を示した。

また，OKT 8 抗体と反応するリンパ球数 (suppressor/cytotoxic) は, 血友病Aの 1 例（症 例 6 ）に拈いて著明な減少を示したが，血友病 B症例を含めた他の症例では全て正常範囲内に 分布した.

さらに, T cell subsets の OKT 4/OKT 8 比を求めると，血友病 $\mathrm{A}$ 全例が 正常值下限の 1.2 以下を示した.

な拈，血友病 B 4 例中 3 例に拈いても， OKT 
4/OKT 8 比の低下（1.2 以下）を認めた.

\section{IV. 考察ならびに結論}

AIDS の診断で, 細胞性免疫の低下が重要な 基準となることが米国 CDC およびわが国厚生 省 AIDS 研究班で認められたが，すでに AIDS の発症が報告されている血友病で8-12)，わが国 の患者ではこの免疫学的変化がどのように認め られるか, 果してこの変化が AIDS の感染(かり に本症候群が病源体による感染症であると仮定 して）にどのように呼応するか，またこの変化 があれば他の臨床症状や検査所見がなくても， AIDS の潜伏期にあるものと解せられるか，あ るいは血液製剤の輸注だけで, 病源体の感染と は全く無関係に免疫機能が低下するものか，な どに関して疑問が残されている15).

そこで著者らは現在血液濃縮製剤療法をうけ ている血友病 21 例につき, 細胞性免疫機能の検 索を行なったところ, 免疫異常を示しながら臨 床症状に欠けるものの極めて多いことを見出し た、すなわち血友病 $\mathrm{A}$ 患者および $\mathrm{B}$ 患者のリン パ球について, monoclonal 抗体を使用した $\mathrm{T}$ 細胞 subsetによる分析を行ならと, OKT ${ }^{4+}$ 対 $\mathrm{OKT}^{8+}$ の比の低下，ことに $\mathrm{OKT}^{4+}$ 細胞数の 減少が有意に認められるほか，T細胞コロニ一 形成不全も抗こり，K-562 細胞を標的とした NK 細胞の活性低下も認められ，これらは比較 的よく呼応したが，しかしこれらの所見から直 ちに各種臨床症状や検査所見を示さない症例を 全て潜在性 AIDS とする積極的な情報は得られ なかった。

また一方血液製剤の輸注により，受注者が本 来持っている免疫機構の変化, 例えば低下ない

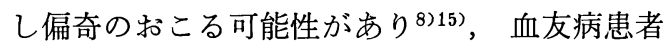
の場合も長年にわたる血液製剤の輸注により, 免疫機能の低下寸ることも, この立場から理解 される.

したがって，これらの免疫機能の変化と， AIDS の感染ないし発症との因果関係を検討す るには,さらに各種免疫機能の分劃的検索, 経時 的追跡とともに, 発熱やリンパ節腫脹, 脾腫, 肝腫, 肺や皮膚の病的所見, 出血性素因などを 同時に注意深く観察することが大切で，これら
を含めた報告を次回に行いたいと思う．

\section{文献}

1) Siegal F.P., Lopez, C., Hammer, G.S. et al. : Severe immunodeficiency im male homosexuals, manifested by chronic perianal ulcerative herpes simplex lesions. N. Engl. J. Med., 305; 1431 1438, 1981.

2) Fornfiels H., Vande Stouwe R.A., Lange, M.. Reddy, M.M. et al.: T-lymphocytes subpopulations in homosexual men N. Engl. J. Med., 307; 729 731, 1982.

3) Follansbee, S.E., Busch, D.F., Wofsy, C.B. et al.: An outbreak of Pneumocystis carinii pneumonia in homosuxal men. Ann. Intern. Med., 96; 705 713, 1982.

4) Stahl, R.E., Friedman-Kien, A., Bubin, R. et al.: Immunologic abnormalities in homosexual men; relationship to Kaposi's sarcoma. Am. J. Med., 73; 171 178, 1982.

5) Mildvan, D., Mathur, U. Enlow, R.W., et al.: Opportunistic infections and immune deficiency in homosexual men. Ann. Intern. Med., 96; 705 713, 1982.

6) Friedman-Kien, A.E., Laubenstein, L.J., Rubinstein P. et al.: Disseminated Kaposi's sarcoma in homosexual men. Ann. Intern. Med., 96; 693 700, 1982.

7) Wormser, G.P., Krupp. L.B., Hanrahan, J.P. et al. : Acquired immunodeficiency syndrome in male prisoners, New insights into an emerging syndrome. Ann. Intern. Med., 98; 297 303, 1983.

8) Lererman, M.M. Ratnoff, O.D. Scillian, J.J. et al.: Impaired cell-mediated immunity in patients with classic hempohilia. N. Engl. J. Med., 308; 79 83, 1983.

9) Nenitove, J.E., Aster, R.H., Casper, J.T. et al.: T-lymphocyte subpopulations in patients with classic hemophilia treated with cryoprecipitate and lyophilized concentrates. N. Engl. J. Med., 308; 83 86, 1983.

10) Davis, K.C., Horsburgh, C.R., Hashiba, U. et al.: Acquired immunodeficiency syndrome in a patient with hemophilia. Ann. Intern. Med., 98; 284 286, 1983. 
11) Poon, M.C., Landay, A., Prasthofer, F. et al.: Acquired immunodeficiency syndrome with Pneumocystis carinii pneumonia and Mycobacterium avium-intracellulare infection in a previously healthy patient with classic hemophilia. Clinical, immunologic and virologic findings. Ann. Internl. Med., 98; 287 290, 1983.

12) Elliot, J.L., Hoppes, W.L., Platt, M.S. et al. : The acquired immunodeficiency syndrome and Mycobacterium avium-intracellulare bacteremia in a patient with hemophilia. Ann. Intern. Med., 98; 290 293, 1983.
13）広見義光，吉村祐一，三宅和彦，他：Campylobacter fetus による敗血症を起こした血友病 $\mathrm{A}$ の 1 例, 第 329 回日本内科学会 関東地方会口 演, 東京, 1983 .

14）仁保喜之：ヒト骨髄細胞による in vitro コロ 二一形成法. 免疫実験操作法, VII. p. 933 938, 日本免疫学会, 1979 .

15) Goldsmith, J.C., Moseley, P.L., Monick, M. et al.: T-lymphocytes subpopulation abnormalities in apparently healthy patients with hemophilia. Ann. Intern. Med., 98; $294 \sim 296,1983$.

\section{○細胞分化の正常亡異常!}

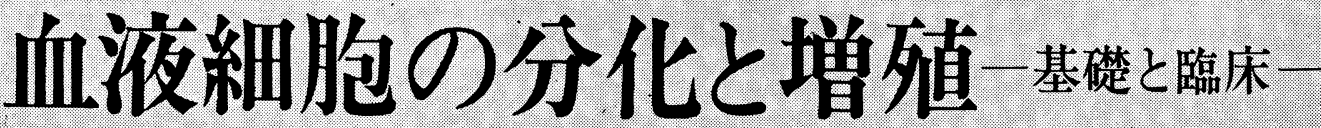

編集 自治医科大学学長 中尾喜久 自治医科大学教授 高久史栕

専門医21氏分担執筆

\section{A 5 判 25I頁 図126 表47 定価4,800円(干200円)}

租液細胞とその分化は近年における血液学の中で最も目覚ましい発展をとげた分野であ る。造血臓器では分化という過程が胎生期のみならず成体にも営まれ, 現在医学の当面し ている重大な問題である「細胞の癌化」にも密接な関係をもっている。本書は今までの歴 史的展望，世界の現況を概説し，わが国での第一線の優れた研究をまとめた良書である。

○内客：1.幹細胞研究の歴史的展望, 2. 骨能增殖性将患における幹細胞の变動, 3.小児血液疾患における 造血幹細胞の動態, 4.Erythropoietin研究の最近の進步, 5.赤血球系細胞の分化, 6. 造血幹細胞の增殖分 化機構の異常としての白血病発症機構の実験的研究, 7.尿エリトロポエチンの免疫化学的研究, 8. 造血幹 細胞の増殖に及ぼす各種異種抗血清の影響, 9.無形成骨能道の造血回復機構一大動脈吻合パラビオージスに よる白血球分化の研究一, 10. 造血の “場”の概念とその役割, 11. 造血細胞のピリミジン代謝調節，12. 造 血細胞のDNA合成の調節, 13.Tーリンパ球の分化, 14. ヒトリンパ采細胞の分化と成熟一臨床例の検討か らの考察一。 